\title{
Cooperation for Development
}

\section{The Soviet Union in the United Nations Development System ${ }^{1}$}

\section{Larionova}

Marina Larionova - PhD, Head, Centre for International Institutions Research (CIIR), Russian Presidential Academy of National Economy and Public Administration (RANEPA); Professor, Faculty of World Economy and International Affairs, National Research University Higher School of Economics; 11 Prechistenskaya naberezhnaya, Moscow, 119034, Russian Federation; E-mail: larionova-mv@ranepa.ru

\footnotetext{
Abstract

The study of the evolution of international cooperation for development in the United Nations (UN) system from 1946 to 2000 reveals that political and ideological contradictions and priorities exerted significant influence on the system's construction, creating barriers to negotiating resolutions and forging decisions and constraining progress in development cooperation.

This article reviews the USSR's initiatives and positions on concrete areas of cooperation, drawing on an analysis of the resolutions and records of the meetings of the UN General Assembly (GA) and the Economic and Social Council (ECOSOC). It highlights the main trends and cases reflecting the Soviet Union's priorities and its role in the evolution of cooperation for development under UN auspices.

Content analysis of meeting records helps to trace the official positions of delegations, problems in advancing cooperation, opportunities for building coalitions, difficulties forging compromises and constraints stemming from the failure to pursue an integrated and comprehensive approach to the resolution of development and international financial/economic problems.

The USSR actively contributed to deliberations and decision-making on a wide range of cooperation for development issues, promoting the primacy of the principles of national policy, developing countries' sovereignty over their natural resources and the right of their exploitation, development of countries' economic potential through support for industrialization, technology transfer, agricultural and national cadre development, and the creation of the necessary external conditions for the mobilization of developing countries' own resources.

These principles, the pursuit of change in the international balance of economic power and the drive for an expansion of influence defined the Soviet Union's initiatives and its support for developing countries on such issues as global negotiations aimed at the establishment of a new international economic order as proposed by the Group of 77(G77) - this call was blocked by the Group of 7(G7) using the Versailles formula to safeguard the independence of the specialized agencies.

Inability to allocate substantial amounts of funding significantly weakened the USSR's influence on decisions defining the parameters of development support mechanisms. Telling examples include the failure to promote the establishment of the UN capital development fund or to counter the assertion of the dollar monopoly in the UN cooperation for development system.

The solidarity of the USSR and the U.S. with their respective allies frequently led to opposition on issues

${ }^{1}$ The editorial board received the article in September 2018.

This research was carried out with the financial support of the Russian Foundation for Basic Research within the framework of a research project entitled "Evolution of Multilateral Development Cooperation Under the Auspices of the United Nations: From Development Decade to Sustainable Development Goals (SDGs)," project no 18-014-00008.
} 
which did not contradict either of the opponents' interests. A case in point is the struggle around the participation of the German Democratic Republic and the Federal Republic of Germany in the UN conference on human environment in Stockholm.

Distrust and tough opposition caused multiple lost opportunities, including a chance to generate additional resources for development through the conversion of resources released by disarmament to peaceful needs.

At the end of the 1990s, following the economic crises of the previous decades, a series of external debt crises and assessment of accumulated data on aid effectiveness and donor fatigue, the principles promoted by the USSR in the first decades of cooperation for development were reflected in the Agenda for Development and the Millennium Declaration.

Key words: cooperation for development; the UN; General Assembly; ECOSOC; UNDP; international financial institutions; the USSR

For citation: Larionova M. (2019) The Soviet Union in the United Nations Development System. International Organisations Research Journal, vol. 14, no 1, pp. 145-163 (in English). DOI: 10.17323/19967845-2019-01-09

The study of the evolution of international cooperation for development in the United Nations (UN) system from 1946 to 2000 [Larionova, Safonkina, 2018] reveals that political and ideological contradictions and priorities exerted significant influence on the construction of the system, creating barriers to negotiating resolutions and forging decisions and thereby constraining progress in development cooperation. The review of the USSR's initiatives and positions on concrete areas of cooperation presented in this article draws on analysis of the resolutions and records of the meetings of the General Assembly (GA) and the UN's Economic and Social Council (ECOSOC). Content analysis of the records of GA meetings helps to trace the official positions of delegations, problems in advancing cooperation, opportunities for building coalitions, difficulties in forging compromises and constraints stemming from the failure to pursue an integrated and comprehensive approach to resolution of international development, financial and economic problems. While this article cannot present a comprehensive picture of the USSR's interaction with its UN partners on the entire spectrum of development issues, it does highlight the main trends and cases that illustrate the Soviet Union's priorities and role in the evolution of cooperation for development under UN auspices.

\section{Formation of Development Cooperation Instruments: Missed Opportunities}

The USSR actively participated in decision-making, often supporting the proposals of developing countries advanced by the Group of 77 (G77), putting forward its own initiatives, and openly opposing decisions affecting the interests of the Union. From the very beginning of the creation of development cooperation mechanisms, the position of the USSR reflected its aspiration for strengthening the UN bodies. Thus, at the second session the USSR proposed a resolution on the implementation of recommendations on economic 
and social matters ${ }^{2}$ aimed at raising the level of compliance with GA recommendations. The goal was to create a feedback system: the GA formulates recommendations in accordance with Article 64 of the UN Charter, the secretary-general reports to the ECOSOC, and the ECOSOC reports to the GA on implementation of ECOSOC and GA recommendations by member countries. The USSR did not participate in the creation of the International Bank for Reconstruction and Development (IBRD) or the International Monetary Fund (IMF), therefore, it did not use the GA and ECOSOC platform to influence the policies of these organizations, which it viewed as being influenced by the United States. For example, when voting on agreements with specialized organizations (World Health Organization (WHO), Universal Postal Union (UPU), International Telecommunication Union, IBRD and IMF) [UN, 1947], the USSR proposed separate votes on each organization and while it did not object to agreements with the IBRD and the IMF, it abstained from voting on them. At the third session, when discussing the resolution on economic development of underdeveloped countries [UN, 1948a], the USSR supported the proposal to facilitate the process of obtaining IBRD loans, expressing hope that the resolution would spur the ECOSOC's work, while at the same time stressing that the Bank did not pay enough attention to underdeveloped countries, and instead acted as a U.S. tool assisting economically developed countries [UN, 1948b].

The desire to change the balance of power in international economic relations and expand its own influence, the need for resources to restore its own economy after World War II, a frankly critical attitude toward the IBRD and the IMF, and confrontation with the U.S. and its allies were all reflected in the position of the USSR at the first stage of the formation of development cooperation mechanisms. A good example is the discussion on the draft resolution of the seventh session of the GA on financing economic development of underdeveloped countries. The draft resolution contained several issues, including the right of countries to exploit their own natural wealth and resources, ${ }^{3}$ the establishment of appropriate and fair prices on the international market and the establishment of the International Finance Corporation (IFC). Discussion and voting went on separately for each of the projects. The United States and its allies opposed the right to free exploitation of natural wealth and resources, fearing the nationalization of the property of private investors without guarantees of mandatory compensation from governments [UN, 1952a, pp. 496-8]. For its part, the USSR did not support the creation of the IFC, believing that: "the assistance which the United States claims to give in reality causes a deterioration in the position of the under-developed countries, since it is accompanied by the imposition on those countries of conditions which place them under the economic, political and even military control of the United States... The credits granted to certain underdeveloped countries by

${ }^{2}$ A/RES/119 (II). Implementation of Recommendations on Economic and Social Matters; The resolution was proposed in implementation of the UN Charter Art. 55 // The UN GA. Available at: http://www.un.org/en/charter-united-nations/index.html (accessed 19 November 2018).

${ }^{3}$ Put forward by developing countries and actively promoted by India, Indonesia, Saudi Arabia, and some Latin American and Asian delegations. When the United States voted, its allies (Australia, Belgium, Canada, Denmark, France, Iceland, Luxembourg, the Netherlands, New Zealand, Norway, Pakistan, Sweden, the Union of South Africa, and the United Kingdom of Great Britain and Northern Ireland) also opposed. The USSR, the Belarusian Soviet Socialist Republic, China, Czechoslovakia, Greece, Haiti, Poland, Turkey and the Ukrainian Soviet Socialist Republic abstained. 
banks under United States control are being used mainly to expand the production of strategic raw materials, such as uranium, not for the effective economic development of those countries. The USSR delegation is not inclined to overestimate the potentialities of either the special fund or the international finance corporation, which are to be established under the resolutions just adopted by the General Assembly. It is a foregone conclusion that these credit institutions, if established, will operate under the aegis and control of United States financial institutions such as the International Bank for Reconstruction and Development, and will therefore not bring about the desired improvement in the financing of the underdeveloped countries" [UN, 1952a, p. 502]. For the same reason, the USSR did not support funding under the Expanded Programme of Technical Assistance [UN, 1952b], considering it "a link in what is known as President Truman's Point Four programme, and is in no way designed to promote the development of under-developed countries. It is bound up with so-called military assistance, and comprises a system of measures, whose purpose is the subjection of the economies of the under-developed countries to United States control and the use of their territories for the establishment of military bases and military springboards, in fulfillment of the aggressive plans of the United States."

As a priority in development assistance the USSR promoted enhancing economic potential of underdeveloped countries based on exploitation of national natural resources, creating industry and developing agriculture. It also supported the inalienable sovereignty of developing countries over their natural resources and their right to exploit them [UN, 1972, p. 9] as well as the creation of external conditions for development. This approach is reflected in the support given by the USSR and the socialist countries to the Declaration on the Establishment of a New International Economic Order, the programme of action for its implementation [UN, 1974a] and the Charter of Economic Rights and Duties of States [UN, 1974b]. These documents contained principles which were supposed to provide internal and external conditions for the development of states: the sovereign equality of all states, the self-determination of all peoples, the right to adopt the economic system most suitable for development, inalienable sovereignty over natural resources and all economic activities, regulation and supervision of activities of multinational corporations, assistance without political conditions, transformation of the international monetary system to assist developing countries, preferential and non-reciprocal treatment for developing countries, and provision of access to the achievements of science and technology.

These priorities, as well as the socialist ideology and nature of the economic structure, determined the position of the USSR on the IFC and the role of private capital. When negotiating funding mechanisms, the USSR invariably insisted on the preferential use of the UN technical assistance administration system instead of distributing the funds of the Expanded Programme of Technical Assistance between the UN and specialized agencies. At the discussion of the draft resolution of the ninth session on the international flow of private capital to underdeveloped countries [UN, 1954a], the Soviet delegation noted that "the draft resolution submitted by the Second Committee is motivated by these very interests of the exports of capital, and not by the interests of under-developed countries. Foreign capital is directed to those branches of the economy of under-developed countries in which it can bring the highest profits and not to the branches which need to be developed in order to achieve a multilateral development of that economy. It is enough to point out that 
the result of the export of capital to underdeveloped countries, and to the Latin-American countries in particular, is the promotion of a lop-sided, unilateral development of their economy. Moreover, many data were adduced in the Second Committee to show that the exporters of foreign capital were deriving from the underdeveloped countries considerably larger sums in profits and interest than the amount of capital which they invested in those countries. The resolution is aimed at creating more favorable conditions for foreign investments in these countries, but at the same time, the draft resolution contains no provisions protecting the interests of the underdeveloped countries and, in particular, relating to the need to protect national industries from the ruinous competition of foreign capital, to the promotion of the development of the domestic resources which are the basis of a country's economic independence" [UN, 1954b, p. 478].

The inability to allocate significant amounts of funding substantially reduced the USSR's impact on decisions regarding the formation of development cooperation instruments. This was clearly manifested in the process of creating a special UN fund for economic development [UN, 1954c]. The decision to establish a special fund was first made in 1954 at the ninth session; discussions about the goals, modalities of work and methods of financing lasted for several years, ending with the creation of the Special Fund at the 13th session of the GA. Its resources (no more than $\$ 100$ million per year) were sufficient to prepare projects ${ }^{4}$ that could later be financed from other sources, including private capital and World Bank funds, but were not at all sufficient to finance capital development projects. The desire of the USSR and developing countries to further transform the fund from a technical assistance instrument to a capital development fund ${ }^{5}$ was not met, ${ }^{6}$ since the main donors were not ready to support it, and the USSR simply did not have adequate resources. Supporting the proposal of developing countries that "a steadily increasing or a fixed percentage of the resources of the Special Fund should be allocated for the direct financing of industrial construction in under-developed countries on a refundable basis and certainly on favourable terms," the Soviet Union itself offered to provide technical assistance "through contributions in its national currency, research and planning, lending Soviet experts, receiving students for instruction and practical raining, and providing educational and laboratory equipment for the underdeveloped countries" [UN, 1958a, pp. 383-4].

In the debates about the creation of the fund and financing of development programmes, the Soviet Union tried to resist the assertion of the dollar monopoly in the UN development system. The USSR's position on the possibility of making contributions to the fund in national currencies or in other currencies at the request of the fund's members is generally reflected in the soft wording of Paragraph 47 on financing: "Contributions are made by governments in currencies transferable to the greatest possible extent into a currency readily usable by the Fund." However, the financial and economic strength of the U.S., the persistent promotion of the dollar as a currency for the budget ${ }^{7}$ by the U.S. and

\footnotetext{
${ }^{4}$ Article 6 of Resolution 1240: Projects might be in one or a combination of the following forms: surveys, research and personnel training and demonstration, including pilot projects.

${ }^{5}$ For details see Larionova and Safonkina [2018].

${ }^{6}$ In 1965, it was decided that the Special Fund and the Expanded Programme of Technical Assistance would be merged into the United Nations Development Programme.

${ }^{7}$ In particular, the United States initiated resolution A/RES/1021 (XI) on the utilization of convertible currencies when governments provide funding in excess of $\$ 500,000$. The USSR opposed, as well as when coordinating the budgets of funds and programmes [UN, 1956].
} 
its partners and its dominant position as a donor were of decisive importance, ultimately, development budgets were made in dollars.

\section{Allies and Opponents}

The landmark decisions on development assistance adopted at the 16th session (1961) were perceived by the USSR in different ways. Supporting the decision on the "Development Decade" [UN, 1961a] and the establishment of the World Food Programme [UN, 1961b] on a pilot basis, the Soviet Union objected to setting a goal of allocating $1 \%$ of the total national income by all countries [UN, 1961c]. The USSR considered setting the mandatory limit as a violation of the principle of voluntary participation in assistance programmes. The Soviet Union shared the position of the developing countries that "the colonial Powers must compensate the under-developed countries for some, at least, of the wealth which they obtained as a result of exploiting the national resources and the population of the under-developed countries" [UN, 1961d, p. 1110]. The USSR opposed the mobilization of food surpluses for distribution in economically less-developed countries [UN, 1960], considering that the supply of surpluses creates the risk of imbalances in prices and supplies in commodity markets and threatens the marketing of goods and the development of agricultural sectors in developing countries.

The USSR put forward the idea of convening the United Nations Conference on Trade and Development (UNCTAD) at the 18th session, advocating it as a mechanism for the development of trade between countries with different state systems and a first step toward the creation of an international trade organization. The proposal did not find support from the members of the General Agreement on Tariffs and Trade (GATT), ${ }^{8}$ however UNCTAD became a key UN body in the area of trade and development [UN, 1965a].

Together with other socialist countries, the USSR advocated the industrial development of developing countries, the expansion of the scope of industrial projects and technical assistance, and the creation of a specialized organization of industrial development. Statements by official representatives of the USSR are often viewed as ideology and propaganda [Machowski, Schultz, 1987], but they nevertheless characterize the Union priorities and scale of aid. In the early 1970s, the USSR had agreements on assistance and cooperation with 45 developing countries, assisted in building and expanding about 860 different projects, of which more than 400 were already in operation. The amount of credit on prefferencial terms offered by the Soviet Union for the purposes of economic, scientific and technical development to developing countries for the period from 1963 to 1971 had almost doubled and exceeded 5.6 billion roubles. Moreover, about $90 \%$ of those funds were channeled into the development of production, including three-quarters into industry and power [UN, 1973a, p. 6].

The creation of the United Nations Industrial Development Organization [UN, 1965b], supporting both developed and developing countries, has become an important contribution to cooperation for industrialization [UN, 1965b, pp. 324-7]. The USSR consistently defended the universal character of the draft resolution, unsuccessfully seeking to involve the German Democratic Republic (GDR) in this work [UN, 1966a, pp. 10-1].

${ }^{8}$ For details, see Larionova and Safonkina [2018]. 
Allied solidarity often influenced the position of the USSR on resolutions whose essence in general did not contradict the interests of the Union. For example, when discussing the members of the preparatory committee for the development of an international strategy for the second UN Development Decade, the United States pushed through wording on the membership of the committee which allowed the Federal Republic of Germany to be involved [UN, 1968a, Para. 1 and 2]. The USSR's amendment was rejected, the emotional statement by the representative of the Union remained unanswered [UN, 1968b, pp. 4-5] and the delegation voted against the resolution. The same struggle unfolded regarding the participation of the GDR in the UN Conference on the Human Environment. During the discussion on the preparations for the Stockholm conference [UN, 1971], the USSR and other socialist states made an amendment proposing to include the GDR as an official participant. The amendment was rejected in the Second Committee. At the 26th session of the GA the USSR, the socialist states and a number of developing states supported the principle of universality of participation in the conference, and 43 delegations voted in favour of the amendment. However, the United States, the United Kingdom and Australia strongly objected, adhering instead to the Vienna formula. ${ }^{9}$ GDR experts were invited to participate in the conference and take part in its preparation at the working level. The struggle irrationality and wastefulness is striking. It would have been much more efficient to use resources to work together given that four years later, in 1973, the process of admitting the German Democratic Republic and the Federal Republic of Germany to the UN was completed.

\section{Beat Swords Into Ploughshares ${ }^{10}$}

Given the lack of official data, it is difficult to give an accurate assessment of the funds allocated by the USSR for development assistance. According to some calculations, from 1954 to 1991, the volume of Soviet aid amounted to more than $\$ 78$ billion [Machowski, Shultz, 1987]. Certainly, this is significantly less than developed countries allocated. For example, development assistance provided by the United States government after World War II exceeded $\$ 75$ billion by 1973 [UN, 1973a, p. 8]. According to the Organisation for Economic Co-operation and Development (OECD), official U.S. assistance for the period 1960-1991 was \$556.4 billion.

In an effort to increase opportunities for assistance, the USSR proposed at the 13th session of the UN GA (1958) an initiative to stop testing atomic and hydrogen weapons, to reduce the military budgets of the USSR, the U.S., the U.K. and France by $10-15 \%$ and to use part of the savings to assist underdeveloped countries [UN, 1958b]. The United States and its allies strongly opposed the proposal.

Eventually joint work and mutual concessions made it possible to agree on the text and adopt in 1962 a declaration on the conversion of the resources released by disarma-

${ }^{9}$ Articles $81-83$ of the 1969 Vienna Convention. In accordance with the Vienna formula, member states of the United Nations or of any of the specialized agencies or parties to the Statute of the International Court of Justice, and any other state invited by the General Assembly of the United Nations may become parties to the Convention.

${ }^{10}$ Such a hope was expressed by the rapporteur of the Second Committee, introducing the draft resolution on the conversion to peaceful needs of the resources released by disarmament. 
ment [UN, 1962a]. Considering the approval of the declaration as a significant success, the representative of the USSR said: "It is significant that it was drafted jointly by the Soviet Union and the United States, that is to say, by the two great Powers which bear the greatest responsibility for the fate of the world... We hope, in this connection, that the Soviet Union's constructive ideas for a basic economic programme for disarmament, which are reflected to some extent in the Declaration, will be taken into account in any further consideration of this question by United Nations bodies" [UN, 1962b, p. 1171].

A large package of solutions aimed at bridging the gap between developed and developing countries - through, among other things, capital inflows, agrarian reforms, industrialization, eradication of illiteracy, technical assistance and training of qualified personnel - was submitted for the 18th session and included a draft resolution on the conversion of the resources released by disarmament (A/5652, Para. 9). The draft resolution was adopted unanimously. As the representative of Cyprus said: "We have here two aspects that developed during 1963 which should be taken into account: one, the growing awareness that the dangers resulting from the gap between the rich and the poor would become equal, in their threat to humanity, to nuclear war itself; and the other, the possibility of administering to both these great needs by the cut-off of production - it should not be too difficult to reach an agreement for the cut-off of production after the consensus, more or less, between the two nuclear Powers about the "nuclear umbrella." It would be very important from the standpoint of the release of resources that this release should be connected more with the cut-off of production than with general and complete disarmament" [UN, 1963, p. 7]. Reports on the conversion of the resources released by disarmament were subsequently considered every two years until the 25th session (1970) [UN, 1966b], although they were of a rather declarative and passing character.

The USSR and its allies emphasized that disarmament and the easing of political tensions are essential conditions for the implementation of the international development strategy for the second United Nations Development Decade. Speaking at the plenary meeting of the 25th session, the representative of Poland, on behalf of the socialist countries, said: "The elimination of this disparity will require not only the greatest mobilization by individual countries of their own resources, expanded international economic, scientific and technological cooperation and foreign aid, but also the easing of political tensions and the cessation of the arms race, which is consuming the resources for the peaceful development of mankind" [UN, 1970a, pp. 4-5]. The complete disarmament, elimination of nuclear, chemical and bacteriological weapons and their means of delivery, as well as foreign military bases and the peaceful resolution of territorial disputes were formulated as the cornerstone principles and conditions for accelerating social and economic development in the joint statement of eight socialist countries on the draft document on the second Development Decade [UN, 1970b]. The relevant provisions were reflected in the international strategy.

However, the USSR's proposal in 1973 to reduce the military budgets of the permanent members of the UN Security Council by $10 \%$ and to use part of the savings to assist developing countries [UN, 1973b] ${ }^{11}$ caused a strong negative reaction, even though in May

${ }^{11}$ The proposal to reduce military budgets by $10 \%$ envisaged a one-time reduction of the official budgets of the permanent members of the Security Council from the 1973 level and allocation of a certain part of the funds thus released for development purposes. According to calculations, this could make it possible to 
1972 the United States and the USSR had signed an agreement on limiting strategic weapons. The United States, Great Britain, France and their allies questioned the practicality, realism, verifiability, possibility of agreement on the criteria for considering the size of the budget, and the expediency of establishing a direct link between the possible reduction of state military budgets and the obligation to increase government allocations to assist developing countries. The representative of the Chinese delegation accused the USSR of hypocrisy in its proposals and the desire "to cover up [its] own arms expansion and war preparations and shift the responsibility for opposing disarmament on to other countries" [UN, 1973a, p. 11]. The proposal was strongly supported by the Third World countries and the draft resolution was adopted by 83 votes in favour, with two against ${ }^{12}$ and 38 abstentions. ${ }^{13}$ But the hopes for its implementation were clearly not destined to come true.

The question was again raised five years later at the 33rd session [UN, 1978] when negotiations on a new treaty between the USSR and the U.S. on the limitation of strategic offensive arms had been almost completed. ${ }^{14}$ The decision to study the issue of disarmament and development, including the proposal to create an international disarmament fund for development, was included in the agenda as part of a large package of documents on disarmament [UN, 1979a]. In 1982, the GA decided to include the issue of the relationship between disarmament and development as a separate item in its agenda starting from the 40th session [UN, 1952a].

The languid existence of this issue ended with the 1987 International Conference on the Relationship between Disarmament and Development. ${ }^{15}$ The conference was held on the eve of the signing by Mikhail Gorbachev and Ronald Reagan of the permanent Treaty on the Elimination of Intermediate-Range and Shorter-Range Missiles (INF) ${ }^{16}$ in December 1987. The United States did not take part in the conference and refused to take action to implement its decisions. In November 1987, at the 42nd session of the GA, the representative of the United States made a statement: "The United states delegation wishes to announce that it will not participate in whatever action the General Assembly takes on agenda item 69. As is commonly known, the United States believes that disarmament and development are two distinct issues that cannot be considered appropriately in terms of an interrelationship between these two disparate subjects. Consequently, the United States declined to participate in the recent International Conference on this matter, and it refrained from participating in the drafting of draft resolution A/C.1/42/L.74 in the First Committee, the subsequent debate on it in the Committee and its adoption in that Committee. For

allocate additional assistance in the amount of at least $\$ 1$ billion. The GA was supposed to establish an ad hoc committee to distribute funds allocated for development by reducing military budgets.

${ }^{12}$ China and Albania.

${ }^{13}$ Argentina, Australia, Austria, Bahamas, Belgium, Brazil, Canada, Congo, Denmark, France, Federal Republic of Germany, Greece, Guinea, Guyana, Iceland, Ireland, Israel, Italy, Ivory Coast, Jamaica, Japan, Luxembourg, Malawi, Mauritania, Netherlands, New Zealand, Norway, Pakistan, Portugal, South Africa, Sweden, Thailand, Trinidad and Tobago, Turkey, United Kingdom of Great Britain and Northern Ireland, United Republic of Tanzania, United States of America and Zambia.

${ }^{14}$ START 2 was signed by U.S. President Jimmy Carter and secretary-general of the CPSU Central Committee, Leonid Brezhnev, in Vienna on 18 June 1979 but it was not ratified by the United States.

${ }^{15}$ France expressed its willingness to host a conference in Paris in July/August 1986 [UN, 1985] but as a result the conference took place in August/September 1987 in New York [UN, 1987a].

${ }^{16}$ Came into force in May 1988. 
those reasons, the United States delegation requests that the record of today's proceedings reflect the fact that the United States has not participated in the consideration of agenda item 69. At the same time, our delegation takes the opportunity to state that the united States Government does not, and will not, consider itself bound or committed in any way by either the declarations in the Final Document of the recent International Conference or the terms of any resolution adopted here" [UN, 1987b, p. 13].

The signing of the Strategic Arms Reduction Treaties (START 1 in $1991^{17}$ and START 2 in $1993^{18}$ ) did not change the dynamics of the dialogue. Over the years, ${ }^{19}$ resolutions on the relationship between disarmament and development, which had become an integral part of an extensive package of disarmament issues, essentially limited themselves to recalling the provisions of the Final Act and calling for measures to implement the action programme adopted at the conference, directing part of the funds released through the implementation of agreements on disarmament and limiting armaments for socio-economic development [UN, 1996].

Mutual mistrust and tough confrontation became the causes for the missed opportunities to attract additional resources for the implementation of development objectives.

\section{The Thorny Path to Restructuring International Economic Relations}

The principles and approaches of the USSR, based on the view that development was possible only in the context of international economic relations built on a fair, equitable and democratic basis, determined the position of socialist countries on the issue of global negotiations aimed at "establishing a new system of international economic relations based on the principles of equality and mutual benefit" [UN, 1979b, pp. 1925-6] initiated by the G77.

The USSR has consistently advocated an integrated and coordinated approach to solving the problems that hindered growth and exacerbated the steady decline of the global economy, including "halting the outflow of real resources from the developing countries resulting from the activities of private foreign capital, primarily the transnational corporations, and from the policy of protectionism, the lowering of world commodity prices, the voluntarist financial policy of the leading Western countries, the unjust international monetary system, the export of inflation to the developing countries" [UN, 1982b, p. 1926]. On this issue, the countries of the G77, the USSR, the socialist countries and China spoke from common positions, very clearly articulated by the representative of China at the 37th session of the GA: "The most widespread and persistent economic recession since the war originated in the developed countries. It has, however, brought serious and unprecedented difficulties to everyone, and to the developing countries in particular. The turbulence in the international financial and monetary system has further aggravated the sense of crisis. On the contrary, it is precisely the malfunctioning of and imbalances in existing international relations that constitute important factors in aggravating the economic crisis. As the

\footnotetext{
${ }^{17}$ Came into force in 1994.

${ }^{18}$ Ratified by the United States in 1996 and by Russia in 2000 .

${ }^{19}$ Every year up to the 55th session, inclusive.
} 
developing countries have consistently maintained, only a radical reform of international economic relations and the establishment of a new international economic order can create the conditions necessary for the recovery of the world economy and, in particular, for the development of the developing countries. The global negotiations are an important effort aimed at achieving this goal" [UN, 1982b, p. 1923].

The question crawled from year to year to the 45 th session, inclusive. But, in fact, comprehensive negotiations never started. At the 40th session, it was decided that the draft agenda of the 41st session would include negotiations on international economic cooperation for development. Further, development issues were discussed mainly in the context of preparing a new international development strategy for the fourth UN Development Decade: development of technology, power, agriculture and industry in connection with relevant industrial programs; solving external debt problems in the framework of resolutions on monetary issues; and problems of state responsibility for economic policies in connection with the review of the implementation of the Charter of Economic Rights and Duties of States. These long years of negotiations about negotiations ended ina deadlock due to the position of the United States and its partners [UN, 1982b, pp. 1922-4], which insisted on "guarantees of the independence of specialized agencies" 20 according to the Versailles G7 formula [G7, 1982]. ${ }^{21}$

Indeed, the IMF and the IBRD, established as specialized structures of the UN, quickly achieved functional independence [IMF, 1947] and as a result the relationship between these institutions and the UN has never worked in accordance with the original intent. Moreover, "the richest and most powerful states effectively limit the UN's role in global economic governance. For this reason, the ECOSOC was never able to effectively perform its task of coordinating the political and economic aspects of global affairs... As a result, national governments, corporations and the institutions themselves were deprived of the opportunity to learn about more integrated approaches to the governance of international financial and economic affairs and transactions that may have developed if the ECOSOC had been able to play its intended role" [Bradlow, 2018].

\section{After 1991}

After the collapse of the USSR, the Russian Federation became the successor of the Union in the UN, assuming all its rights and obligations. In 1992, Russia became a member of the IMF and the World Bank. Russia's integration into the world economic community took place in the midst of a deep crisis of the national economy. In 1992, large-scale reforms were launched to facilitate the transition from a planned to a market economy, and a long period of recession began. In 1992-1999, Russia's gross domestic product fell by 36\%, and the share of the Russian economy in the global economy decreased from $3.2 \%$ in 1992 to $1.9 \%$ in 1999 . The crisis severely limited the resources available to implement international commitments to assist development. The Russian Federation began to receive international assistance and turned from a donor country into a recipient country. The restoration of

\footnotetext{
${ }^{20}$ IMF, WB and GATT.

${ }^{21}$ For the details on the G7's position, see Larionova and Safonkina [2018].
} 
Russia's donor potential began only in the 2000s with the beginning of the growth of the national economy [Larionova, Rakhmangulov, 2016; Kolmar, Sakharov, 2019].

Transformation in the international economic system affected cooperation for development. In the 1990s, developing countries several times raised the question of the impact of this evolution on economic growth, believing that support extended to Eastern and Central European countries could lead to an outflow of, or decrease in, development assistance to developing countries whose economies were also affected by changes in economic relations with the former socialist countries [UN, 1991a].

In 1994, the elaboration of a comprehensive agenda for development began. It has absorbed all the issues, including the impact of globalization and the end of the Cold War on addressing development challenges. The Agenda for Development [UN, 1991b], adopted on 20 June 1997 without a vote at the 103rd plenary session of the GA, stated that economic development, social development and environmental protection are interdependent and mutually complementary components of sustainable development, for which peace and security are required. Russia participated in drafting the Agenda provisions that included "acknowledging the primacy of national policy and measures in the development process and calling for action toward a dynamic and enabling international economic environment, including an open, rule-based, equitable, secure, non-discriminatory, transparent and predictable multilateral trading system and promotion of investment and transfer of technology and knowledge, as well as for enhanced international cooperation in the mobilization and provision of financial resources for development from all sources, the strategy for durable solutions to the external debt and debt-servicing problems of developing countries and the efficient use of available resources" [UN, 1992, Para. 2]. The Agenda for Development reflected all the priorities and principles that the USSR had promoted for many years. Russia supported the document.

\section{Conclusion}

The USSR actively contributed to deliberations and decision-making on a wide range of cooperation for development issues, promoting the principles of the primacy of national policies, developing countries' inalienable sovereignty over their natural resources and the right of their exploitation, development of the countries' economic potential through support to industrialization, technology transfers, agricultural and national cadre development, and the creation of the necessary external conditions to mobilize developing countries' own resources.

These principles, the pursuit of change in the balance of power in international economic relations and the drive for expanded influence defined the nature of the Soviet Union's initiatives and its support of the developing countries on such issues as global negotiations aimed at establishment of a new international economic order as proposed by the G77 but blocked by the G7 Versailles formula.

Inability to allocate substantial amounts of funding significantly weakened the USSR's influence on decisions defining the parameters of development support mechanisms. Telling examples include the failure to promote the establishment of the UN capital development fund or to counter the assertion of the dollar monopoly in the UN cooperation for development system. 
The solidarity of the USSR and the U.S. with their respective allies frequently led to opposition on issues which did not contradict either of the opponents' interests. A case in point is the struggle around the participation of the German Democratic Republic and the Federal Republic of Germany in the UN conference on human environment in Stockholm.

Distrust and tough opposition caused multiple lost opportunities including a chance to generate additional resources for development through the conversion of resources released by disarmament to peaceful needs.

At the end of the 1990s, following the economic crises of the previous decades, a series of external debt crises and assessment of accumulated data on aid effectiveness and "donor fatigue" [Keeley, 2012], the principles promoted by the USSR in the first decades of cooperation for development were reflected in the Agenda for Development and the Millennium Declaration.

\section{References}

Bradlow D. (2018) Assessing the Potential for Global Economic Governance Reform. International Organisations Research Journal, vol. 13, no 4, pp. 213-236.

Group of 7 (G7) (1982) Declaration of the Seven Heads of State and Government and Representatives of the European Communities. Versailles, 6 June. Available at: http://www.g8.utoronto.ca/ summit/1982versailles/communique.html (accessed 19 November 2018).

International Monetary Fund (IMF) (1947) Agreement Between the United Nations and the International Monetary Fund. Available at: https://www.imf.org/external/SelectedDecisions/Description. aspx?decision=DN5 (accessed 19 November 2018).

Keeley B. (2012) From Aid to Development: The Global Fight Against Poverty. OECD Publishing. Available at: https://www.oecd-ilibrary.org/docserver/9789264123571-en.pdf?expires=1542720874\&id=id\&a ccname $=$ guest $\&$ checksum $=$ EBBAB6A686FB1DA1FD177D0FB7E8BB8E.

Kolmar O.I., Sakharov A.G. (2019) Russia and the SDGs: The National and International Aspects. Bulletin of International Organizations, vol. 14, no 1. (In Russian)

Larionova M., Rakhmangulov M. (2016) Russia: A Re-emerging Donor. The BRICS in International Development: The State of the Debate (J. Gu, A. Shankland, A. Chenoy (eds)). Palgrave Macmillan.

Larionova M., Safonkina E. (2018) The First Five Decades of Cooperation for Development: Actors, Achievements and Challenges. International Organisations Research Journal, vol. 13, no 4, pp. 96-136.

Machowski H., Schultz S. (1987) Soviet Economic Policy in the Third World. International Studies, vol. 24, no 3, pp. 225-247.

United Nations (UN) (1947) Agreements with Specialized Agencies. General Assembly Resolution A/ RES/124 (II). Available at: https://undocs.org/en/A/RES/124(II) (accessed 19 November 2018).

United Nations (UN) (1948a) Economic Development of Under-Developed Countries. General Assembly Resolution A/RES/198 (III). Available at: https://undocs.org/en/A/RES/198(III) (accessed 19 November 2018).

United Nations (UN) (1948b) One Hundred and Seventieth Plenary Meeting of the General Assembly. Available at: http://www.un.org/en/ga/search/view_doc.asp?symbol=A/PV.170 (accessed 19 November 2018).

United Nations (UN) (1952a) Official Records of the General Assembly, Seventh Session. Available at: https://undocs.org/en/A/PV.411 (accessed 19 November 2018).

United Nations (UN) (1952b) Expanded Programme of Technical Assistance for the Economic Development of Under-Developed Countries. General Assembly Resolution A/RES/621. Available at: http:// www.un.org/en/ga/search/view_doc.asp?symbol=A/RES/621(VII) (accessed 19 November 2018).

United Nations (UN) (1954a) International Flow of Private Capital for the Economic Development of Under-Developed Countries. General Assembly Resolution A/RES/824. Available at: https://doc- 
uments-dds-ny.un.org/doc/RESOLUTION/GEN/NR0/095/59/IMG/NR009559.pdf?OpenElement (accessed 19 November 2018).

United Nations (UN) (1954b) Official Records of the General Assembly, Ninth Session. Available at: https://undocs.org/en/A/PV.510 (accessed 19 November 2018).

United Nations (UN) (1954c) Question of the Establishment of a Special United Nations (UN) Fund for Economic Development. General Assembly Resolution A/RES/822(IX). Available at: http://www. un.org/en/ga/search/view_doc.asp?symbol=A/RES/822(IX) (accessed 19 November 2018).

United Nations (UN) (1956) Currency Utilization. General Assembly Resolution A/RES/1021 (XI). Available at: https://undocs.org/en/A/RES/1021(XI) (accessed 19 November 2018).

United Nations (UN) (1958a) Official Records of the General Assembly, Thirteenth Session. Available at: https://undocs.org/en/A/PV.776 (accessed 19 November 2018).

United Nations (UN) (1958b) Question of Disarmament. General Assembly Resolution A/RES/1252 (XIII). Available at: https://undocs.org/en/A/RES/1252(XIII) (accessed 19 November 2018).

United Nations (UN) (1960) Provision of Food Surpluses to Food-Deficient Peoples Through the United Nations (UN) System. General Assembly Resolution A/RES/1496 (XV). Available at: https://undocs. org/en/A/RES/1496(XV) (accessed 19 November 2018).

United Nations (UN) (1961a) United Nations (UN) Development Decade - A Programme for International Economic Cooperation. General Assembly Resolution A/RES/1710 (XVI). Available at: https:// undocs.org/en/A/RES/1710(XVI) (accessed 19 November 2018).

United Nations (UN) (1961b) World Food Programme. General Assembly Resolution A/RES/1714 (XVI). Available at: https://undocs.org/en/A/RES/1714(XVI) (accessed 19 November 2018).

United Nations (UN) (1961c) Reaffirmation of General Assembly Resolution 1522 (XV) On the Accelerated Flow of Capital and Technical Assistance to the Developing Countries. General Assembly Resolution A/RES/1711 (XVI) (accessed 19 November 2018).

United Nations (UN) (1961d) Official Records of the General Assembly, Sixteenth Session. Available at: https://undocs.org/en/A/PV.1084 (accessed 19 November 2018).

United Nations (UN) (1962a) Declaration on the Conversion to Peaceful Needs of the Resources Released by Disarmament. General Assembly Resolution A/RES/1837 (XVII). Available at: https://undocs. org/en/A/RES/1837(XVII) (accessed 19 November 2018).

United Nations (UN) (1962b) Official Records of the General Assembly, Seventeenth Session. Available at: https://undocs.org/en/A/PV.1197 (accessed 19 November 2018).

United Nations (UN) (1963) Official Records of the General Assembly, Eighteenth Session. Available at: https://undocs.org/en/A/PV.1276 (accessed 19 November 2018).

United Nations (UN) (1965a) Establishment of the United Nations (UN) Conference on Trade and Development as an Organ of the General Assembly. General Assembly Resolution A/RES/1995 (XIX). Available at: https://undocs.org/en/A/RES/1995(XIX) (accessed 19 November 2018).

United Nations (UN) (1965b) Establishment of the United Nations (UN) Organizations for Industrial Development. General Assembly Resolution A/RES/2089 (XX). Available at: https://undocs.org/en/A/ RES/2089(XX) (accessed 19 November 2018).

United Nations (UN) (1966a) Official Records of the General Assembly, Twenty-First Session. Available at: https://undocs.org/en/A/PV.1468 (accessed 19 November 2018).

United Nations (UN) (1966b) Conversion to Peaceful Needs of the Resources Released by Disarmament. General Assembly Resolution A/RES/2171 (XXI). Available at: https://undocs.org/en/A/ RES/2171(XXI) (accessed 19 November 2018).

United Nations (UN) (1968a) International Development Strategy. General Assembly Resolution A/ RES/2411 (XXIII). Available at: https://undocs.org/en/A/RES/2411(XXIII) (accessed 19 November 2018).

United Nations (UN) (1968b) Official Records of the General Assembly, Twenty-Third Session. The UN GA. Available at: https://undocs.org/en/A/PV.1745 (accessed 19 November 2018).

United Nations (UN) (1970a) Official Records of the General Assembly, Twenty-Fifth Session. Available at: https://undocs.org/en/A/PV.1883 (accessed 19 November 2018).

United Nations (UN) (1970b) Letter Dated 21 September 1970 from the Permanent Representatives of Bulgaria, the Byelorussian Soviet Socialist Republic, Czechoslovakia, Hungary, Mongolia, Poland, the 
Ukrainian Soviet Socialist Republic and the Union of Soviet Socialist Republics to the UN addressed to the SG. General Assembly Agenda Item A/8074. Available at: https://undocs.org/en/A/8074 (accessed 19 November 2018).

United Nations (UN) (1971) United Nations Conference on the Human Environment. General Assembly Resolution A/RES/2850 (XXVI). Available at: https://undocs.org/en/A/RES/2850(XXVI) (accessed 19 November 2018).

United Nations (UN) (1972) Official Records of the General Assembly, Twenty-Seventh Session. Available at: https://undocs.org/en/A/PV.2113 (accessed 19 November 2018).

United Nations (UN) (1973a) Official Records of the General Assembly, Twenty-Eighth Session. Available at: https://undocs.org/en/A/PV.2194 (accessed 19 November 2018).

United Nations (UN) (1973b) Reduction of the Military Budgets of States Permanent Members of the Security Council by 10 Per Cent and Utilization of Part of the Funds Thus Saved to Provide Assistance to Developing Countries. General Assembly Resolution A/RES/3093. Available at: https://undocs.org/ en/A/RES/3093(XXVIII) (accessed 19 November 2018).

United Nations (UN) (1974a) Resolutions Adopted on the Report of the Ad Hoc Committee of the Sixth Special Session. Available at: https://undocs.org/en/A/RES/3201(S-VI) (accessed 19 November 2018).

United Nations (UN) (1974b) Charter of Economic Rights and Duties of States. General Assembly Resolution A/RES/3082 (XXVIII). Available at: https://undocs.org/en/A/RES/3281(XXIX) (accessed 19 November 2018).

United Nations (UN) (1978) Review of the Implementation of the Recommendations and Decisions Adopted by the General Assembly at its Tenth Special Session. General Assembly Resolution A/ RES/33/71. Available at: https://undocs.org/en/A/RES/33/71 (accessed 19 November 2018).

United Nations (UN) (1979a) Study of the Relationship Between Disarmament and Development. General Assembly Resolution A/RES/34/83K. Available at: https://undocs.org/en/A/RES/34/83 (accessed 19 November 2018).

United Nations (UN) (1979b) Official Records of the General Assembly, Thirty-Fourth Session. Available at: https://undocs.org/en/A/34/PV.104 (accessed 19 November 2018).

United Nations (UN) (1982a) Relationship Between Disarmament and Development. General Assembly Resolution A/RES/37/84. Available at: https://undocs.org/en/A/RES/37/84 (accessed 19 November 2018).

United Nations (UN) (1982b) Official Records of the General Assembly, Thirty-Seventh Session. Available at: https://undocs.org/en/A/37/PV.113 (accessed 19 November 2018).

United Nations (UN) (1985) Relationship between Disarmament and Development. General Assembly Resolution A/RES/40/155. Available at: https://undocs.org/en/A/RES/40/155 (accessed 19 November 2018).

United Nations (UN) (1987a) Relationship Between Disarmament and Development. General Assembly Resolution A/RES/42/45. Available at: https://undocs.org/en/A/RES/42/45 (accessed 19 November 2018).

United Nations (UN) (1987b) Provisional Verbatim Record of the Eighty-Fifth Meeting. Available at: https://undocs.org/en/A/42/PV.85 (accessed 19 November 2018).

United Nations (UN) (1991a) Impact of the Recent Evolution of East-West Relations on the Growth of the World Economy, in Particular on the Economic Growth and Development of the Developing Countries, as Well as on International Economic Cooperation. General Assembly Resolution A/RES/46/202. Available at: https://undocs.org/en/A/RES/46/202 (accessed 19 November 2018).

United Nations (UN) (1991b) Agenda for Development. General Assembly Resolution A/RES/51/240. Available at: http://undocs.org/A/RES/51/240 (accessed 19 November 2018).

United Nations (UN) (1992) Impact of the Recent Evolution of the Economies in Transition on the Growth of the World Economy, in Particular on the Economic Growth and Development of the Developing Countries, As Well As on International Economic Cooperation. General Assembly Resolution A/ RES/47/175. Available at: https://undocs.org/en/A/RES/47/175 (accessed 19 November 2018).

United Nations (UN) (1996) General and Complete Disarmament. General Assembly Resolution A/ RES/50/70. Available at: https://undocs.org/en/A/RES/50/70 (accessed 19 November 2018). 


\title{
СССР в системе сотрудничества в целях развития под эгидой $\mathrm{OOH}^{1}$
}

\author{
М.В. Ларионова
}

Ларионова Марина Владимировна - д.полит.н., директор Центра исследований международных институтов (ЦИМИ) Российской академии народного хозяйства и государственной службы при Президенте РФ (РАНХиГС); профессор факультета мировой экономики и мировой политики Национального исследовательского университета «Высшая школа экономики»; Российская Федерация, 119034, Москва, Пречистенская наб., д. 11; E-mail: larionova-mv@ranepa.ru

Исследование эволюции международного сотрудничества в целях развития под эгидой ООН в период с 1946 по 2000 г. показывает, что политические и идеологические противоречия и приоритеты участников оказывали значительное влияние на процесс формирования системы, создавали барьеры в согласовании подходов и решений, становились сдерживающим фактором для прогресса в содействии развитию.

Представленное в статье исследование позиций и инициатив СССР по конкретным направлениям сотрудничества опирается на анализ текстов резолюций и официальных отчетов ключевых органов ООН, прежде всего Генеральной Ассамблеи (ГА) и Экономического и Социального Совета ООН (ЭКОСОС). Основная задача работы состояла в том, чтобы проследить тенденции и представить характерные примеры, которые позволяют читателю сформировать понимание приоритетов и роли СССР в эволюции международного сотрудничества в целях развития под эгидой $О \mathrm{OH}$.

Контент-анализ текстов официальных отчетов заседаний ГА позволяет выявить официальные позиции делегаций, проблемы выстраивания сотрудничества, возможности формирования коалиций, трудности поиска компромиссов и ограничения, связанные с невозможностью реализации интегрированного подхода к решению проблем развития и международных финансовых и экономических вопросов.

Анализ показывает, что СССР активно участвовал в формировании решений по содействию развитию, продвигая принципы примата национальной политики, неотвемлемого суверенитета развивающихся стран над своими естественными ресурсами и права на их эксплуатацию, развития собственного экономического потенциала на основе индустриализации и передачи технологий, развития сельского хозяйства и национальных кадров, создания внешних условий для мобилизации собственных ресурсов развивающихся стран.

Эти принципы, а также стремление изменить расстановку сил в международных экономических отношениях и расширить собственное влияние определяли характер инициатив СССР и поддержку предложений развивающихся стран по таким вопросам как глобальные переговоры, направленные на «создание новой системы международных экономических отношений, основанной на принципах равноправия и взаимной выгоды», инициированных Группой 77 и заблокированных «версальской формулой» «руппы семи».

Невозможность выделения значительных объемов финансирования существенно ослабляла влияние СССР на решения о формировании инструментов содействия развитию, наглядным примером чего стали нежизнеспособность идеи учреждения Фонда капитального развития ООН и неспособность противостоять утверждению монополии доллара в системе развития ООН.

Солидарность СССР со своими союзниками, с одной стороны, и США с их партнерами, с другой, зачастую приводила к противостоянию по вопросам, суть которых не противоречила интересам ни той ни другой стороны. Примером является борьба вокруг участия ГДР и ФРГ в Конферениии ООН по проблемам окружающей человека среды.

Недоверие и жесткое противостояние стало причиной многих упущенных возможностей, в том числе привлечения дополнительных ресурсов для реализации задач развития в результате переключения на мирные нужды ресурсов, высвобождаемых в результате разоружения.

В коние 90-х годов после экономических кризисов 70-х и 80-х, нескольких кризисов внешней задолженности, анализа данных об эффективности официальной помощи развитию и накопившейся «донорской усталости», принципы, которые СССР продвигал в первые десятилетия содействия развитию, нашли отражение в Повестке дня для развития и Декларации тысячелетия Организации Объединенных Наций.

${ }^{1}$ Статья поступила в редакцию в сентябре 2018 г.

Исследование выполнено при финансовой поддержке РФФИ в рамках проекта проведения научных исследований «Эволюция многостороннего сотрудничества по содействию развитию под эгидой ООН: от декады развития к Целям устойчивого развития (ЦУР)», проект № 18-014-00008. 
Ключевые слова: сотрудничество для развития; ООН; Генеральная Ассамблея; ЭКОСОС; ПРООН; международные финансовые учреждения; СССР

Для цитирования: Ларионова М.В. (2019) СССР в системе сотрудничества в целях развития под эгидой ООН // Вестник международных организаций. Т. 14. № 1. C. 145-163. DOI: 10.17323/1996-7845-2019-01-09

\section{Источники}

Колмар О.И., Сахаров А.Г. (2019) Россия и ЦУР: национальный и международный аспекты // Вестник международных организаций. Т. 14. № 1.

Ларионова М.В., Сафонкина Е.А. (2018) Первые десятилетия сотрудничества для развития. Участники, достижения и трудности // Вестник международных организаций. 2018. T. 13. № 4. C. 96. DOI: 10.17323/1996-7845-2018-04-05

Организация Объединенных Наций (ООН) (1945) Устав ООН. Режим доступа: http://www.un.org/ru/ charter-united-nations/index.html (дата обращения: 19.11.2018).

Организация Объединенных Наций $(\mathrm{OOH})(1947 \mathrm{a})$ Проведение в жизнь рекомендаций по экономическим и социальным вопросам. Резолюция Генеральной Ассамблеи A/RES/119 (II). Режим доступа: http://www.un.org/ru/documents/ods.asp?m=A/RES/119(II) (дата обращения: 19.11.2018).

Организация Объединенных Наций $(\mathrm{OOH})(1947 b)$ Соглашения со специализированными организациями. Резолюция Генеральной Ассамблеи A/RES/124 (II). Режим доступа: http://www.un.org/ru/ documents/ods.asp?m=A/RES/124(II) (дата обращения: 19.11.2018).

Организация Объединенных Наций (ООН) (1948а) Экономическое развитие малоразвитых стран. Резолюция Генеральной Ассамблеи A/RES/198 (III). Режим доступа: http://www.un.org/ru/documents/ ods.asp?m=A/RES/198(III) (дата обращения: 19.11.2018).

Организация Объединенных Наций (ООН) (1948b) One Hundred and Seventieth Plenary Meeting of the General Assembly. Режим доступа: http://www.un.org/en/ga/search/view_doc.asp?symbol=A/PV.170 (дата обращения: 19.11.2018).

Организация Объединенных Наций (ООН) (1952a) Генеральная Ассамблея. Седьмая сессия. Официальные отчеты. Режим доступа: https://undocs.org/ru/A/PV.411 (дата обращения: 19.11.2018).

Организация Объединенных Наций (ОOH) (1952b) Expanded Programme of Technical Assistance for the economic development of under-developed countries. Резолюция Генеральной Ассамблеи A/RES/621. Режим доступа: http://www.un.org/en/ga/search/view_doc.asp?symbol=A/RES/621(VII) (дата обращения: 19.11.2018).

Организация Объединенных Наций (ООН) (1954a) International flow of private capital for the economic development of underdeveloped countries. Резолюция Генеральной Ассамблеи A/RES/824. Режим доступа: https://documents-dds-ny.un.org/doc/RESOLUTION/GEN/NR0/095/59/IMG/NR009559.pdf?Open Element (дата обращения: 19.11.2018).

Организация Объединенных Наций $(\mathrm{OOH})(1954 b)$ Генеральная Ассамблея - Девятая сессия - Пленарные заседания. Режим доступа: https://undocs.org/ru/A/PV.510 (дата обращения: 19.11.2018).

Организация Объединенных Наций (ООН) (1954c) Question of the establishment of a special United Nations fund for economic development. Резолюция Генеральной Ассамблеи A/RES/822(IX). Режим доступа: http://www.un.org/en/ga/search/view_doc.asp?symbol=A/RES/822(IX) (дата обращения: 19.11.2018).

Организация Объединенных Наций $(\mathrm{OOH})(1958 \mathrm{a})$ Генеральная Ассамблея. Тринадцатая сессия. Официальные отчеты. Режим доступа: https://undocs.org/ru/A/PV.776 (дата обращения: 19.11.2018).

Организация Объединенных Наций (ООН) (1958b) Вопрос о разоружении. Резолюция Генеральной Ассамблеи A/RES/1252 (XIII). Режим доступа: http://www.un.org/ru/documents/ods.asp?m=A/ RES/1252(XIII) (дата обращения: 19.11.2018).

Организация Объединенных Наций (ООН) (1960) Снабжение народов, испытывающих недостаток в продовольствии, продовольственными излишками через посредство учреждений, входящих в систему ООН. Резолюция Генеральной Ассамблеи A/RES/1496 (XV). Режим доступа: http://www.un.org/ru/ documents/ods.asp?m=A/RES/1496(XV) (дата обращения: 19.11.2018). 
Организация Объединенных Наций (ООН) (1961a) «Декада развития» ООН - программа международного экономического сотрудничества. Резолюция Генеральной Ассамблеи A/RES/1710 (XVI). Режим доступа: http://www.un.org/ru/documents/ods.asp?m=A/RES/1710(XVI) (дата обращения: 19.11.2018).

Организация Объединенных Наций (ООН) (1961b) Мировая продовольственная программа. Резолюция Генеральной Ассамблеи A/RES/1714 (XVI). Режим доступа: http://www.un.org/ru/documents/ods. asp?m=A/RES/1714(XVI) (дата обращения: 19.11.2018).

Организация Объединенных Наций (ОOH) (1961c) Подтверждение резолюции 1522 (XV) Генеральной Ассамблеи относительно ускоренного притока капитала и технической помощи в развивающиеся страны. Резолюция Генеральной Ассамблеи A/RES/1711 (XVI). Режим доступа: http://www.un.org/ ru/documents/ods.asp?m=A/RES/1711(XVI) (дата обращения: 19.11.2018).

Организация Объединенных Наций (ООН) (1961d) Генеральная Ассамблея. Тринадцатая сессия. Официальные отчеты. Режим доступа: https://undocs.org/ru/A/PV.1084 (дата обращения: 19.11.2018).

Организация Объединенных Наций (ООН) (1962a) Декларация о переключении на мирные нужды ресурсов, высвобождаемых в результате разоружения. Резолюция Генеральной Ассамблеи A/RES/1837 (XVII). Режим доступа: https://undocs.org/ru/A/RES/1837(XVII) (дата обращения: 19.11.2018).

Организация Объединенных Наций (OOH) (1962b) Генеральная Ассамблея. Семнадцатая сессия. Официальные отчеты. Режим доступа: https://undocs.org/ru/A/PV.1197 (дата обращения: 19.11.2018).

Организация Объединенных Наций (ООН) (1963) Генеральная Ассамблея. Восемнадцатая сессия. Официальные отчеты. Режим доступа: https://undocs.org/ru/A/PV.1276 (дата обращения: 19.11.2018).

Организация Объединенных Наций (OOH) (1965a) Учреждение Конференции ООН по торговле и развитию в качестве органа Генеральной Ассамблеи. Резолюция Генеральной Ассамблеи A/RES/1995 (XIX). Режим доступа: http://www.un.org/ru/documents/ods.asp?m=A/RES/1995(XIX) (дата обращения: 19.11.2018).

Организация Объединенных Наций (OOH) (1965b) Создание ООН по промышленному развитию. Резолюция Генеральной Ассамблеи A/RES/2089 (XX). Режим доступа: http://www.un.org/ru/documents/ ods.asp?m=A/RES/2089(XX) (дата обращения: 19.11.2018).

Организация Объединенных Наций (ООН) (1966а) Генеральная Ассамблея. Двадцать первая сессия. Официальные отчеты. Режим доступа: https://undocs.org/ru/A/PV.1468 (дата обращения: 19.11.2018).

Организация Объединенных Наций (ООН) (1966b) Переключение на мирные нужды ресурсов, высвобождаемых в результате разоружения. Резолюция Генеральной Ассамблеи A/RES/2171 (XXI). Режим доступа: http://www.un.org/ru/documents/ods.asp?m=A/RES/2171(XXI) (дата обращения: 19.11.2018).

Организация Объединенных Наций (ООН) (1968а) Международная стратегия развития. Резолюция Генеральной Ассамблеи А/RES/2411 (XXIII). Режим доступа: http://www.un.org/ru/documents/ods. asp?m=A/RES/2411(XXIII) (дата обращения: 19.11.2018).

Организация Объединенных Наций (ООН) (1968b) Генеральная Ассамблея. Двадцать третья сессия. Официальные отчеты. Режим доступа: https://undocs.org/ru/A/PV.1745 (дата обращения: 19.11.2018).

Организация Объединенных Наций (OOH) (1970a) Генеральная Ассамблея. Двадцать пятая сессия. Официальные отчеты. Режим доступа: https://undocs.org/ru/A/PV.1883_(дата обращения: 19.11.2018).

Организация Объединенных Наций (ООН) (1970b) Letter Dated 21 September 1970 from the Permanent Representatives of Bulgaria, the Byelorussian Soviet Socialist Republic, Czechoslovakia, Hungary, Mongolia, Poland, the Ukrainian Soviet Socialist Republic and the Union of Soviet Socialist Republics to the UN addressed to the SG. General Assembly Agenda Item A/8074. Режим доступа: https://undocs.org/en/A/8074 (дата обращения: 19.11.2018).

Организация Объединенных Наций (ООН) (1971) Конференция ООН по проблемам окружающей человека среды. Резолюция Генеральной Ассамблеи A/RES/2850 (XXVI). Режим доступа: http://www. un.org/ru/documents/ods.asp?m=A/RES/2850(XXVI) (дата обращения: 19.11.2018).

Организация Объединенных Наций (OOH) (1972) Генеральная Ассамблея. Двадцать седьмая сессия. Официальные отчеты. Режим доступа: https://undocs.org/ru/A/PV.2113 (дата обращения: 19.11.2018).

Организация Объединенных Наций (OOH) (1973a) Генеральная Ассамблея. Двадцать восьмая сессия. Официальные отчеты. Режим доступа: https://undocs.org/ru/A/PV.2194 (дата обращения: 19.11.2018).

Организация Объединенных Наций (ООН) (1973b) О сокращении военных бюджетов государств постоянных членов Совета Безопасности ООН на 10 процентов и об использовании части сэкономленных средств на оказание помощи развивающимся странам. Резолюция Генеральной Ассамблеи 
A/RES/3093 (XXVIII). Режим доступа: https://undocs.org/ru/A/RES/3093(XXVIII) (дата обращения: 19.11.2018).

Организация Объединенных Наций $(\mathrm{OOH})$ (1974а) Генеральная Ассамблея - Шестая специальная сессия. Резолюции, принятые по докладу Специального комитета шестой специальной сессии. Режим доступа: https://undocs.org/ru/A/RES/3201(S-VI) (дата обращения: 19.11.2018).

Организация Объединенных Наций (ООН) (1974b) Хартия экономических прав и обязанностей государств. Резолюция Генеральной Ассамблеи A/RES/3082 (XXVIII). Режим доступа: https://undocs.org/ ru/A/RES/3281(XXIX) (дата обращения: 19.11.2018).

Организация Объединенных Наций (ООН) (1978) Рассмотрение осуществления рекомендаций и решений, принятых Генеральной Ассамблеей на ее десятой специальной сессии. Режим доступа: https:// undocs.org/ru/A/RES/33/71 (дата обращения: 19.11.2018).

Организация Объединенных Наций $(\mathrm{OOH})(1979 a)$ Исследование взаимосвязи между разоружением и развитием. Резолюция Генеральной Ассамблеи A/RES/34/83K. Режим доступа: http://www.un.org/ ru/documents/ods.asp?m=A/RES/34/83 (дата обращения: 19.11.2018).

Организация Объединенных Наций $(\mathrm{OOH})(1979 b)$ Генеральная Ассамблея. Тридцать четвертая сессия. Официальные отчеты. Режим доступа: https://undocs.org/ru/A/34/PV.104 (дата обращения: 19.11.2018).

Организация Объединенных Наций $(\mathrm{OOH})$ (1982a) Взаимосвязь между разоружением и развитием. Режим доступа: https://undocs.org/ru/A/RES/37/84 (дата обращения: 19.11.2018).

Организация Объединенных Наций $(\mathrm{OOH})$ (1982b) Генеральная Ассамблея. Тридцать седьмая сессия. Официальные отчеты. Режим доступа: https://undocs.org/ru/A/37/PV.113 (дата обращения: 19.11.2018).

Организация Объединенных Наций (ООН) (1985) Взаимосвязь между разоружением и развитием. Режим доступа: https://undocs.org/ru/A/RES/40/155_(дата обращения: 19.11.2018).

Организация Объединенных Наций $(\mathrm{OOH})(1987 \mathrm{a})$ Взаимосвязь между разоружением и развитием. Режим доступа: https://undocs.org/ru/A/RES/42/45 (дата обращения: 19.11.2018).

Организация Объединенных Наций (ООН) (1987b) Генеральная Ассамблея. Сорок вторая сессия. Предварительный стенографический отчет о 85-м заседании. Режим доступа: https://undocs.org/ ru/A/42/PV.\%2085 (дата обращения: 19.11.2018).

Организация Объединенных Наций (ООН) (1991а) Воздействие происходящей в последнее время эволюции отношений между Востоком и Западом на рост мировой экономики, в частности на экономический рост и развитие развивающихся стран, а также на международное экономическое сотрудничество. Резолюция Генеральной Ассамблеи А/RES/46/202. Режим доступа: https://undocs.org/ru/A/ RES/46/202 (дата обращения: 19.11.2018).

Организация Объединенных Наций (ООН) (1991b) Agenda for Development. Резолюция Генеральной Ассамблеи A/RES/51/240. Режим доступа: http://undocs.org/A/RES/51/240 (дата обращения: 19.11.2018).

Организация Объединенных Наций $(\mathrm{OOH})(1996)$ Всеобщее и полное разоружение. Режим доступа: https://undocs.org/ru/A/RES/50/70_(дата обращения: 19.11.2018).

Bradlow D. (2018) Assessing the Potential for Global Economic Governance Reform. International Organisations Research Journal. Vol. 13. No. 4. P. 213.

Group of 7 (G7) (1982) Declaration of the Seven Heads of State and Government and Representatives of the European Communities. Versailles. 6 June. Режим доступа: http://www.g8.utoronto.ca/summit/1982versailles/ communique.html (дата обращения: 19.11.2018).

International Monetary Fund (IMF) (1947) Agreement Between the United Nations and the International Monetary Fund. Режим доступа: https://www.imf.org/external/SelectedDecisions/Description.aspx? decision=DN5 (дата обращения: 19.11.2018).

Larionova M., Rakhmangulov M. (2016) Russia: A Re-emerging Donor // The BRICS in International Development: The State of the Debate / J. Gu, A. Shankland, A. Chenoy (eds.). Palgrave Macmillan.

Machowski H., Schultz S. (1987) Soviet Economic Policy in the Third World // International Studies. Vol. 24. No. 3. P. 225-247.

OECD (2012) From Aid to Development. The Global Fight against Poverty. Режим доступа: https://www. oecd-ilibrary.org/docserver/9789264123571-en.pdf?expires=1542720874\&id=id\&accname=guest\&checksum =EBBAB6A686FB1DA1FD177D0FB7E8BB8E (дата обращения: 19.11.2018). 